Polgári Szemle, 15. évf. 1-3. szám, 2019, 413-423., DOI: 10.24307/psz.2019.0927

Kerekes Etelka

\title{
Az állam gazdasági szerepe Gazdasági folyamatok és kontrollingtechnikák alkalmazásának kapcsolata
}

\author{
The Economic Role of the State
}

Correlation Between Economic Procedures and Controlling Techniques

\section{ÖSSZEFOGLALÁS}

A gazdaság szempontjából az állam különbözô jogszabályi és intézményi rendszerein keresztül, ezek múködtetésével jelenik meg. A modern társadalmakban alapvetố funkciók határozzák meg az állam szerepét, azaz az ország közös ügyeinek intézését: jogi keretek, gazdaságpolitikai beavatkozások, versenyszabályozás, uniós és nemzetközi kapcsolatok, alapvetô szolgáltatások, infrastruktúra, szociális szerepek, környezetvédelem. Ezen feladatok ellátásához a szükséges forrásokat a beszedett adók biztosítják.

Journal of Economic Literature (JEL) kódok: E02, G2, N4, E5, E62

Kulcsszavak: állam, gazdasági folyamatok, belsố kontrollrendszer, gazdaságbefolyásoló eszközök, fenntarthatóság

\section{SUMmary}

In an economic perspective, the state is manifest through various legal and institutional systems and their operation. In modern societies, the role of the state, in other words, the administration of a country's public affairs, is determined by fundamental functions: the legal frameworks, the economic policy interventions, competition regulation, European Union and international relations, the fundamental services, the infrastructure, social roles and environmental protection. The funds required for the performance of these duties are raised from taxes.

Journal of Economic Literature (JEL) codes: E02, G2, N4, E5, E62

Keywords: state, economic procedures, internal control system, economy influencing tools, sustainability

Kerekes Etelka PhD-hallgató, Szent István Egyetem Gazdálkodás és Szervezéstudományok Doktori Iskola (etelka.kerekes@gmail.com). 


\section{Tudományos múhely}

Az állami funkciók között jelentôs súlyt képvisel a gazdasági tevékenység befolyásolása és felügyelete, ellenôrzése, amely elsôsorban a vállalatokkal való együttmúködésben jelentkezik. Az állami feladatok ellátását korlátozhatják a globalizációs folyamatok, mint például a multinacionális vállalatokra való „ráhatási lehetôség”. Ezek a multik a számukra nem megfelelô gazdaságpolitika esetén akár el is hagyhatják az országot, vagy különféle tevékenységekkel befolyásolják azt.

A gazdasági folyamatokat nagyon sok objektív és szubjektív tényezô befolyásolja. Ugyanakkor a gazdasági folyamatok összetettsége miatt sokszor nehezen felismerhetôk a problémák („pókháló tétel”), azok hatásai a nemzetgazdaság egészére nézve.

A gazdASÁGPOLITIKA, A GAZDASÁG BEFOLYÁSOLHATÓSÁGÁNAK GAZDASÁGPOLITIKAI ESZKÖZEI

Az állam hatalmi befolyását gazdaságpolitikai eszközökkel éri el. A mindenkori gazdaságpolitikai eszközök kombinációit és azok hatását (pozitív vagy negatív) ugyan különbözó matematikai modellekkel, számításokkal is próbálják leírni, de a gazdasági folyamatok nem mindig a „kétszer kettô négy” alapján múködnek.

A gazdasági folyamatok a szúkösen rendelkezésre álló termelési tényezók (föld a természeti kincseivel, a munkaerô, a tôkke, technika-tudomány stb.) mennyiségi, minôségi és strukturális öszszefüggései alapján változnak, s ezek globális összefüggései alapján szükséges egy adott nemzetgazdaság fejlôdésének, fejlesztésének befolyásolására a különbözô makroökonómiai, politikai, gazdaságpolitikai eszközök kombinációit összeállítani és alkalmazni. Azt is tudjuk, hogy nincs két azonos feltételekkel múködô gazdaság: ami az egyik gazdaság esetében az eloony, a másik gazdaság esetében hátrányt jelent. A közgazdászok többsége nem fogadja el a gazdasági folyamatokra vonatkozóan a „csak így, és nem másképp” elvet. A sokféle eszköz sokféle kombinációjának nagyon sokféle hatása lehet a gazdaság különbözô szintjeire (szektoraira, tényezôiire stb.).

A történelmi ismereteink azt jelzik, hogy egy gazdaságban a „mit, hogyan, kinek" kérdésekre is különbözô gazdasági rendszerekben alkalmazott eszközkombinációkat lehet alkalmazni, s az azonos makrogazdasági célok (pl. növekedjen a gazdasági kibocsátás, alacsonyan lehessen tartani a munkanélküliséget, az inflációt, egyensúlyban tartani a külkereskedelmi export-import folyamatokat, a fenntartható fejlődés kritériumainak megfelelően irányítani a folyamatokat, stb.) ellenére nem minden nemzetgazdaság fejlódése, fejlesztése tudja az emberiség jólléti igényei szerinti eredményeket elérni. Ezen folyamatok utasításos és/vagy piacgazdasági rendszereinek fejlesztési folyamatait jelentôs részben az adott ország, nemzetgazdaság irányítására, befolyásolására megválasztott, kijelölt mindenkori kormányzat által választott gazdaságpolitikai eszközök határozzák meg (a természeti tényezôk hatásait is megpróbálva felismerni). Az adott kormányzat által választható gazdaságpolitikai eszközök lehetnek a fejlődést elősegítô, ösztönzó (expanzív), illetve a fejlódést gátló (restriktív) eszközök is.

Napjainkban a regnáló gazdaságpolitika a piacgazdasági rendszer folyamatainak befolyásolására tesz kísérletet. Hazánkban is a rendszerváltás után a 


\section{Tudományos múhely}

piacgazdasági (szociális piacgazdaság) rendszer kiépítését hirdette meg az elsố kormány, megpróbált olyan, a gazdaság befolyásolására alkalmas eszközök kombinációit kidolgozni, bevezetni, amely eredményeként létrejött volna a piacgazdaság.

Vita volt és van ma is a közgazdászok között, hogy milyen szerepet vállaljon az állam a gazdasági folyamatokba való beavatkozásra:

- nôjön az állam gazdasági szerepe, beavatkozása;

- vagy csökkenjen;

- milyen mély és széles legyen a köre az állam által felvállalt feladatoknak?

$\mathrm{Az}$ is kérdés, hogy a szükségletek kielégítése szempontjából mit bízzanak a piacra, a piac önszabályozó szerepére, s az alkalmazásra kerülô eszközök milyen köre legyen direkt, illetve indirekt gazdaságszabályozó eszköz.

Azt is tudjuk, hogy a gazdasággal, annak befolyásolásával nem lehet ellenórzött kísérletet folytatni: hogy kísérletezzünk néhány évig, és ha ennek az eredménye nem tetszik, vagy nem értékeljük pozitívként a gazdasági hatását, akkor „kiöntsük”, és kezdjünk újabb kísérletekbe. Ugyanis a gazdasági folyamatok során akkor is megtörténik a termelési tényezôk felhasználása, ha annak eredményét késôbb nem megfelelố gazdasági útnak értékeljük; ezt nevezhetjük a termelési tényezôk pazarlásának is, és természetesen nem ez a cél a szúkösen rendelkezésre álló gazdasági tényezôk felhasználási folyamataiban. A gazdálkodó szervezetek (üzleti vállalkozások, költségvetési szervek, nonprofit szervezetek stb.) gazdálkodásának ellenôrzési rendszerét is azért szükséges kiépíteni és fejleszteni, hogy a gazdasági tényezôk felhasználásával minél gazdaságosabb, hatékonyabb és ered- ményesebb legyen a gazdasági szereplôk tevékenysége, a fogyasztási igények kielégítése.

Ugyanakkor azt is tapasztalhattuk már, hogy az egyes választási ciklusokban az egymást követố kormányok nem mindig folytatják az elôzố kormányok által elindított folyamatokat, még akkor sem, ha a gazdaság egészére pozitív hatások érvényesülnek, hanem teljesen más felfogás alapján indítanak újabb gazdasági programokat, gazdaságpolitikai eszközkombinációkat. Ezért tanúi lehetünk olyan üzleti szervezeti reagálásoknak, hogy nem tartják be vagy nem akarják betartani az állam által szükségesnek ítélt gazdasági szabályokat, törvényeket, rendeleteket, mondván, az üzleti szervezetek profitérdekeit ezek sértik. (Az üzleti szervezetek és az állam és intézményei között kialakuló ellentétek a szúkösen rendelkezésre álló források pazarlásához vezetnek!)

Szinte minden kormány azt szeretné elérni, hogy a gazdasági növekedést befolyásoló tényezôket (termelố alapok oldaláról ható, a munkaerố-, a tôke, technika, tudás oldaláról ható extenzív és intenzív tényezôk mennyiségét, minôségét és struktúráját) ismerve, a gazdasági folyamatokat a gazdasági növekedés (a nemzetgazdasági kibocsátás bôvülése, bôvítése) szolgálatába állítsa, hogy a szúkösen rendelkezésre álló termelési tényezôk felhasználásával a minél magasabb szükségletkielégítési színvonalat érhesse el.

Az állam gazdasági beavatkozása eredményessége értékelésénél jelentôs szempontok a következók:

- A gazdaság befolyásolásának folyamataiban érvényesül-e a tényezók felhasználásának hatékonysága (pl. ne az állami 


\section{Tudományos múhely}

beavatkozás eredményeképpen legyen a tényezőfelhasználás pazarló, nem hatékony); „az állam legyen a hatékonyság ôre” követelmény.

- A kormányzati beavatkozás során a folyamatok stabilitást eredményezóen menjenek végbe ( $p l$. az állami beavatkozás ne naponta változzon, és nem is egy irányba, amelynek következtében a gazdasági szereplôk nem tudják hosszabb távra a profitmaximalizálási követelményeket sem tervezni, egy ciklusban sokszori szabályozóváltozás kiszámíthatatlanságot, instabilitást eredményez, és inkább a szabályozók kijátszására való figyelés lesz a tevékenységük, mint a hatékony, stabil termelés, szolgáltatás végzése; az adók, elvonások gyakori változtatása inkább a jövedelem eltitkolására ösztönöz, nem a tisztességes bevallásra, az adók megfizetésére stb.); „az állam legyen a stabilitás ôre" követelmény.

- A kormányzati beavatkozások az igazságosságot erôsítsék a gazdasági szereplőkben - bár ez a követelmény a legnehezebben teljesíthetô, és politikai szempontból is nagyon kényelmetlen lehet az igazságosság határainak megnevezése és annak betartása, betartatása, mert mi az igazságos pl. az elosztási kérdésekben, ki kapjon alanyi jogon segélyt, lakást, ellátást stb. Mi legyen a szociális igazságosság kritériuma? Ez „az állam legyen az igazságosság ôre" követelmény.

AZ ÁlLAM GAZDASÁGI BEAVATKOZÁSÁNAK FISKÁLIS ESZKÖZEI

A gazdaság folyamatainak a költségvetésen (költségvetési politikai eszközök) keresztüli befolyásolását nevezzük fiskális gazdasági eszközöknek. Az állami költségvetés bevételei és kiadásai mennyisége és szerkezete az egyes idôszakokban vál- tozhat, a bevételek és kiadások egyenlegének jellege is jelentôs hatású lehet a gazdasági folyamatokra. A bevételek szolgálnának általában az állam által felvállalt (gazdasági, szociális, kulturális, oktatási, honvédelmi, igazgatási stb.) feladatok finanszírozására. A kiadások mennyisége és struktúrája megmutatja, hogy melyek azok a feladatok, amelyeket az állam preferál vagy gátol, s milyen mértékben.

Amennyiben a bevételek kisebbek, mint a kiadások, akkor beszélünk költségvetési hiányról (deficit), s ebben az esetben az állam, az általa felvállalt feladatokat nem tudja teljesíteni. Azonban, ha mégis akarja, akkor pótlólagos bevételi forrásokat kell felkutatni (pl. újabb adók, illetékek, járulékok bevezetése, a bevétel növelése érdekében, a kiadási szükségletek fedezésére stb.), vagy be kell „vallania”, hogy túlvállalta a feladatokat, és pl. a piaci területre bízza ezeket, így akinek van jövedelme, az ki tudja ezeket a szükségleteit elégíteni, akinek nincs, az pedig nem. A gazdasági „növekedés” úgy is befolyásolható, hogy a gazdasági folyamatok adott szintjénél újabb adókat vetnek be, azonban arra figyelemmel kell lenni, hogy kibírják e gazdasági szereplők, vagy gátolnák az újabb elvonások a gazdasági szereplók beruházási, fejlesztési terveit, így a vállalkozások oldaláról szúkülhet a kibocsátás. Amennyiben a bevételek nagyobbak, mint a tervezett kiadások, akkor beszélünk a költségvetési többletrôl (szufficit). Ebben az esetben a korábban felvállalt feladatok teljesíthetôk, sốt maradhat viszonylagos szabad bevétel pótlólagos feladatok felvállalására is, vagy elôrehozhatók késóbbre tervezett állami beruházások, fejlesztések is. A jelenkori történelemben nem gyakori, hogy az állami költségvetések szufficitesek lennének, 


\section{Tudományos múhely}

inkább a deficitesek a jellemzóek (lényeges kormányzati feladatok mostanában a deficit mértékének csökkentésére való törekvésekhez gazdaságpolitikai eszközök kombinációinak a bevezetése.

Sok esetben a deficites költségvetési egyenleg arra is ösztönözheti a kormányzatot, hogy újragondolja az általa felvállalt feladatok mennyiségét, minôségét és szerkezetét, $\mathrm{s}$ ha a gazdasági szakemberek úgy látják, hogy az adott feladatok állam általi lemondása nem okozna jelentôs politikai problémát, akkor az állam késôbbiekben nem vállalja fel azt a feladatot, s ha szükséges azon területnek a szükségletkielégítése, akkor más gazdasági szereplőkre háríthatja. Ilyen lehet például, hogy nem minden szintú oktatási, kulturális, egészségügyi feladatot az állam és intézményeinek kell kielégíteni, lehetséges, hogy nonprofit, civil szervezetek is el tudják vállalni, és ellátását megszervezni (magániskolák, magán-egészségügyi szolgáltatások, magánszínházak).

A fiskális eszközök körébe szokás sorolni az adók, a járulékok, vámok és illetékek különbözô területeit, eszközeinek különbözô kombinációit. Ezen eszközöket is lehet úgy csoportosítani, hogy közvetlen és közvetett befolyásoló eszkö$z \ddot{k}, \mathrm{~s}$ úgy is, hogy növekedést, gazdasági folyamatokat serkentő (expanzív hatás) hatásúak, illetve a növekedést, gazdasági folyamatokat gátló (restriktív hatás) hatásúak. Az üzleti szervezetek gazdálkodását, a vezetôi döntéseket ezen tényezôk nagysága nagymértékben befolyásolja, gondolok itt az adók növelésére, amely nem biztos, hogy mindig úgy hat a gazdasági folyamatokra, hogy több állami bevételt eredményeznek. Vita van az egykulcsos és többkulcsos adók alkalmazásának hatásáról, az egyes adónemekrôl, a helyi és a központi adókról. Befolyásolhatja a gazdasági folyamatokat az is, hogy az országnak van-e lehetôsége vámokat bevezetni, vagy sem. Mostanában többkörös vámmentességben van több velünk kereskedelmi forgalmat lebonyolító ország, ezért nagyon kevés területen tudjuk a vámokat is alkalmazni (EU-tagság, GATT-tagság), tehát erre az eszközre most nem tudunk bevételi forrásként építeni.

A gAZDASÁGI FOLYAMATOK

BEFOLYÁSOLÁSÁNAK MONETÁRIS

POLITIKAI ESZKÖZEI

A gazdasági folyamatok befolyásolásának másik eszközcsoportja a monetáris politikai eszközcsoport, amelyekkel már nem az állami költségvetésen keresztüli gazdasági befolyásolás történik, hanem a pénzpiaci folyamatokon - a pénzkereslet és a pénzkínálat mennyiségének, struktúrájának, egyensúlyának a befolyásolásán - keresztül történik a gazdaság szereplóinek és folyamatainak szabályozása. A pénzfolyamatoknak az árupiaci folyamatokra való hatása fogja befolyásolni, orientálni a gazdasági szereplóket a rendelkezésre álló gazdasági tényezôk felhasználásának gazdaságos, hatékony, eredményes felhasználására, és ezen keresztül a nemzetgazdasági növekedésre, fejlódésre is hatással lesz.

A monetáris eszközök adott idôszakbani kombinációjának kialakítására és érvényesítésére az állam által megfogalmazott gazdaságpolitikai célok, növekedési folyamatok alapján, általában az adott ország jegybankjának vezetésével a pénzügyi rendszer intézményrendszerén (bankrendszer) keresztül kerülhet sor. A monetáris eszközök a gazdasági folyamatokat, gazdasági szereplóket a 


\section{Tudományos múhely}

kamatpolitika, a hitelpolitika eszközein keresztül általában közvetett módon befolyásolják; a pénzkeresletre, illetve a pénzkínálatra hatnak, s ezek hatása válthat ki az árupiacon kereslet-, illetve kínálatnövekedést és -csökkenést, tehát ezeknek is lehetnek expanzív (a gazdasági folyamatokat erôsító, élénkítô) és restriktív hatásai. Például a pénzkínálat növelése során több pénz kerül forgalomba, s akkor ennek lehet kamatcsökkentô hatása. A beruházni szándékozók alacsonyabb kamaton juthatnak hitelhez, a beruházás eredményeként növekszik a kibocsátás, növekedhet a munkaerô-kereslet, a foglalkoztatás, s ennek következményeként több igény jelenik meg az árupiacon, tehát az árupiaci keresletet is növeli. De az ellenkezô folyamatot is fel lehet vázolni: a pénzkínálat csökkenése következtében, ha nagy a hitelkereslet, növekedhet a kamatláb, és magasabb kamaton - a dráguló hitelkamatok miatt több beruházni szándékozó már nem fog hitelt felvenni, nem tud termelést bóvíteni, esetleg csökkenti a termelést, felszabadít, elbocsát munkaerốt, kevesebb lesz az árupiaci kereslet; a kibocsátás lelassul, és restriktív folyamatok indulhatnak be a gazdaságban.

Ezen eszközök között találjuk a nyílt piaci múveleteket (az államkötvények kibocsátása, adásvétele, nagy értékú vagyontárgyak adásvétele, valuták-devizák adásvétele, nemesfémek adásvétele), a rediszkontláb szabályozását (viszontleszámítolási kamatláb) növelése, csökkentése, a tartalékráta szabályozását (a kereskedelmi bankok hitelkínálatát szabályozza).

Az állam a monetáris politikai eszközökön keresztül is befolyásolja az üzleti szervezetek gazdálkodását, ezek is profitszabályozó tényezôk, a vezetôi döntéseket nagyban befolyásolják, mint a pénzügyi környezet elemei.

\section{AZ ÁR-BÉR-JÖVEDELEM SZABÁLYOZÁS ESZKÖZEI}

A gazdasági folyamatok befolyásolásának eszközei közé tartozhatnak az adott gazdaságban az ár- és bér-jövedelem szabályozásának eszközei is. Amennyiben a piaci kereslet és kínálat egyensúlyban tartására szeretné az állam a gazdasági szereplőket orientálni, akkor helyesnek túnik, ha az árak (pl. a munkaerőpiaci árak, a munkabérek) területén is kinyilvánítja, hogy hogyan befolyásolja a bérek alakulását, azok stabilitását milyen eszközökkel szeretné elérni, az állam képviselói a munkaadók és munkavállalók képviselôivel ár-bér szabályozási szerzôdésben egyeznek meg, és mindegyik szerepló („háromszög”) tartja magát a megegyezésben szereplő ár-bér változtatási lehetôségekhez, így kiszámíthatóbbak lesznek a piaci folyamatok is. A gazdasági szereplók a profitmaximalizálási törekvéseikben is a stabilitást tartják szem elótt, így a gazdasági folyamatokra is a stabilitás lehet a jellemzô. Amennyiben a „háromszög” szereplói nem tudnak megegyezni, akkor elófordul, hogy a nem állami szereplók nem tartják be az állam kéréseit, törvényeit, és kiszámíthatatlanság lesz úrrá a piacokon az árak és bérek területén is. Például hiába szeretné az állam az inflációt csökkenteni, ha a vállalkozók felôl az árak emelése érinti a piacot (költségek növekedése vagy a kereslet-kínálat egyensúlytalansága miatt), ezáltal torzulhat az állam antiinflációs célja is; vagy nincs megegyezés, és a piaci szereplók sem bízhatnak az államban, nem tartják be a jogszabályokat, nem fizetik be az adót stb. Az 


\section{Tudományos múhely}

állam ezzel a megállapodással csökkentheti az inflációs várakozásokat is (inflációs várakozások hưtésnek-fútésének hatása a gazdasági folyamatokra).

\section{KÜLKERESKEDELEM-POLITIKAI ESZKÖZÖK}

A nyitott gazdaságokban a gazdasági folyamatok befolyásolásának egyik eszközcsoportja a külkereskedelem-politikai eszközök. Ezen eszközökkel a külkereskedelmi egyensúly létrehozása, illetve megtartása érdekében lehet és kell az államnak a gazdasági folyamatokat befolyásolni, hatni a gazdasági növekedésre, a gazdasági szerkezetre. Itt szükséges megemlíteni az export-import szabályozási eszközöket (áru- és tôkkeexport-import szabályozását, a nettó export növelésének ösztönzési eszközeit, export-import kvótákat), az árfolyam-politikai eszközöket, a vámszabályozást is (bár a vámokról korábban jeleztem, hogy mostanában kevéssé lehet ezzel az eszközzel élni). A kis országok gazdaságai nagymértékben kitettek a nemzetközi piacok vezetố politikai-gazdasági hatásainak, sôt a nemzeti valutánk árfolyamának meghatározása is nagyon nagy mértékben a külkereskedelmi folyamatoktól függ, nem igazán jelentôsek azok az eszközök, amelyekkel saját valutánk árfolyamát meghatározhatnánk. Élhetünk az árfolyam le- és felértékelésének módszereivel, amelyeknek az export- vagy az importösztönzó, illetve -gátló hatásait befolyásolni lehet, de nem tudunk hosszú távon jelentôs befolyást szerezni e területen. Minden gazdasági befolyásolási eszköznek lehetnek gazdasági folyamatokat, növekedést gyorsító vagy lassító hatásai, ezért szükséges az összes eszköz lehetséges kombinációinak együttes hatására többdimenziós, ökonometriai modelleket alkotni (ágazati kap- csolatok mérlege mátrix, ÁKM), számításokat végezni, a modelleket is dinamikus változtatásokkal szükséges újra és újra vizsgálni, s levonni a várható gazdasági hatásokat. De nem szabad száz százalékban bízni abban, hogy a célokat maradéktalanul meg is tudjuk valósítani, mert nincs statikus gazdaság. Fontos a rugalmas gazdaságpolitika gyakorlása, és nem szabad elfelejteni, hogy a gazdasági folyamatok nagyon sok tényezố együttes hatásának eredményeit jelentik.

\section{A BELSÓ KONTROLLRENDSZER MINT A GAZDASÁGI FOLYAMATOK BEFOLYÁSOLÁSÁNAK ESZKÖZE}

Az állami gazdaságpolitikai eszközök kombinációinak alkalmazását segíthetnék a szúkösen rendelkezésre álló közpénzek felhasználásának ellenôrzési rendszerei, intézményei, eszközei, mint pl. a belsố kontrollrendszer intézményi kiépítettsége, a külsố és belsố ellenôrzés intézményei és hatékony múködtetése.

Hazánkban is folyamatosan alakultak ki a külsố ellenôrzés intézményei és a tevékenységüknek keretet szabó jogszabályok (Állami Számvevôszék, Könyvvizsgálói Kamara, Kormányzati Ellenôrzési Hivatal, Európai Uniós Támogatásokat Ellenôrzố Igazgatóság stb.). A közpénzekkel gazdálkodó intézmények, hivatalok vezetôi kötelesek megszervezni az intézményi belsố kontrollrendszert, a független belsô ellenőrzést, az intézményi integritás szabályozását, amelyek megfelelő múködése esetén a közpénzek felhasználása átláthatóbbá válik. A költségvetési szervek vezetôivel szemben elvárás, hogy a szervezet vagyonával (eszközök, források) hatékonyan és eredményesen gazdálkodjanak. Ezek mérésére ki kell alakítani megfele- 


\section{Tudományos múhely}

lő mutatószámokat (teljesítménymutatókat), amelyek a vezetóknek információval szolgálhatnak a szervezeti célok elérése érdekében. A belsô kontrollrendszer is ilyen információval bír, azaz a szervezet céljainak elérésében segíti a vezetôt. Megfelelố kialakítása, múködtetése és fejlesztése a költségvetési szerv vezetôjének felelôssége.

Az állami, költségvetési intézmények gazdálkodásának és az üzleti szervezetek gazdálkodásának belsố kontrollrendszer eszközei, módszerei lényegesen nem különböznek. Az üzleti szervezetek profitérdekeltsége, a tulajdonosi érdek erôsebb megnyilvánulása miatt már természetesebb, jobban kialakult a belsố kontrollrendszer elemeinek kiépítése, az átláthatósági követelmények érvényesítése, mint az állami intézményeknél, ahol a vezetés csak sokszoros közvetítettségen keresztül érzékeli a tulajdonosi érdeket.

A belsố kontrollrendszer elemei a kontrollkörnyezet, a kockázatkezelési rendszer, a kontrolltevékenységek, az információs és kommunikációs rendszer, valamint a nyomon követési (monitoring) rendszer.

Az államháztartási belsố kontrollrendszerre vonatkozóan, nemzetközi ellenôrzési standardokra való tekintettel (amelyeket az üzleti szervezetekre fejlesztettek ki korábban, s az államháztartási rendszerbe az utóbbi 15-20 évben kezdtek bevezetni, alkalmazni), az államháztartásért felelôs miniszter hazai standardokat alakított ki és tett közzé, amelyek megfelelnek az európai uniós követelményeknek is.

Függetlenül attól, hogy egy szervezet a magán- vagy a közszférában végzi a tevékenységét, az biztos, hogy a szervezetet valamilyen cél elérése érdekében hozták létre. Az államigazgatásban ez általában valamilyen közfeladat ellátásához kapcsolódó célokat jelent. A szervezet tevékenységét átszövô belsố kontrollrendszert azért hozták létre, hogy biztosítsa a kitûzött célok elérését. A belsô kontrollrendszer öt elemén belül a kockázatkezelés biztosítja azt, hogy a szervezeti célok elérését veszélyeztetô kockázatok azonosításra, értékelésre és a lehetô legalacsonyabb szintre csökkenthetôek legyenek.

Az ellenôrzések a hatékonysági, gazdaságossági és eredményességi követelmények vizsgálatán keresztül hatást gyakorolhatnak az adott intézmény tevékenységére. Amennyiben az ellenőrzési rendszer általánossá és elfogadottá válik, a szúkösen rendelkezésre álló források felhasználásával is jelentôs hatást lehet gyakorolni a nemzetgazdasági fejlódési folyamatokra. Nélkülözhetetlen a különféle kontrollrendszerek gyakorlása a gazdasági tevékenység, az üzlet, a vállalkozások életében, nagy szükség van a folyamatos visszacsatolásra, a különféle kontrollok gyakorlására. Ahhoz, hogy a vezetók vissza tudjanak tekinteni, és értékelni tudják az elért eredményeket, szükségük van a visszajelzésekre, a káros jelenségeket kiszúrésére, hogy a helytelen, rosszul múködô stratégiákon változtatni tudjanak, garanciát vállaljanak a számadatok megbízhatóságáról, a szabályos múködésról. Ebben a tekintetben a felelôsség ugyanúgy terheli akár az állami, akár az üzleti szektor elsố számú vezetôjét. Az állam szempontjából fontos a megfelelô múködést a köz felé is igazolni, hiszem a köz pénzéból gazdálkodik. A vállalkozásoknál a tulajdonos, a választott könyvvizsgáló, az adóhatóság, az érdekelt helyi civil szervezetek, a hitelezók, a finanszírozó bank stb. is elvárják a szabályszerú, eredményes, hatékony, megbízható mú- 


\section{Tudományos mühely}

ködést. Az ellenôrzés, a visszacsatolás, a folyamatok kontrollja, azaz a belsô kontrollok megfeleló múködése felértékelódött. A vállalatok mára ezt a munkát szervezett keretek között végzik, melyet belsó kontrollrendszernek (internal control system) nevezünk. A belsố kontrollrendszer célja, hogy az állami szervezetek és a vállalat múködésével kapcsolatosan biztosítsa a szabályszerú múködést, az eredmények hatékony elérését, és megbízható beszámolók szülessenek.

A belsố kontrollrendszer követelményeit elsố ízben 1992-ben publikálták keretrendszerként, azóta 2004-ben a kockázatkezeléssel bóvült a modell, és 2013-ban megjelent a keretrendszer módosított, aktualizált második verziója. A belsố kontrollrendszert öt komponensre bontható:

- kontrollkörnyezet, ahol helyet kapnak a kontrollrendszert befolyásoló tényezók, elemek, melyeket a vezetésnek fel kell ismernie és figyelembe kell vennie a szervezet múködtetése során;

- kockázatkezelés, amelyen belül a szervezet beazonosítja az üzleti tevékenységet veszélyeztetô jelenségeket és azok lehetséges hatásait;

- kontrolltevékenységek, amelyeknek keretében alkalmazzák a különféle kontrollokat, ezek mixét, egyúttal kijelölik a felelôseiket, meghatározzák az idôzítést, a gyakoriságot, továbbá a szükséges beavatkozási szinteket, eljárási szabályokat;

- információ és kommunikáció, amelynek segítségével tájékoztatják az érintett külsó és belsố szereplôket a kontrollok gyakorlásával kapcsolatos információkról;

- monitoring, melyek keretében elemzik és értékelik a teljes belsô kontrollrendszer múködését, annak erôs és gyenge pontjait, és fejlesztési javaslatokat dolgoznak ki.
GONDOLATOK A GAZDASÁGI

NÖVEKEDÉSRÓL ÉS A FENNTARTHATÓ

GAZDASÁGRÓL

Az állam hosszú távú legfőbb makrogazdasági, gazdaságpolitikai célja az adott gazdaság rendelkezésre álló erôforrásainak ismeretében a minél nagyobb gazdasági növekedés ösztönzése. A gazdasági növekedés mértékét, a különbözô nemzetgazdaságok összehasonlítását több, kibocsátást mérô mutatószámrendszerrel tudjuk jellemezni (SNA-, ESA-mutatók), amelyek számbavételi elemeiben túlsúlyosak a mennyiségi mutatók, s vannak már minốségi fejlôdést mérô mutatók is. A gazdasági folyamatokat nagyban befolyásolhatják a gazdasági növekedés közvetett (a termeló alapok oldaláról ható) és közvetlen (a munkaerố oldaláról ható) tényezôk mennyiségi, minőségi és strukturális jellemzôi is. Jelentôsége van annak is, hogy az adott ország a gazdasági növekedésnek milyen útját valósítja meg - az extenzív, illetve az intenzív növekedési utat. Napjainkra már nem is a mennyiségi növekedést tekintjük nagyon fontosnak, hanem a minôségi növekedést, fejlôdést, a jóléti mutatókkal jellemezhetô eredményeket.

\section{ÖSSZEFOGLALÁS}

A közgazdászok heves vitákat folytatnak a gazdaságpolitikai gyakorlattal kapcsolatos nézetkülönbségek miatt. Egyes közgazdászok a gazdaságot instabilnak, mások stabilnak gondolják. Abban sokan egyetértenek, hogy az aktív kormányzati politika magától értetôdô, hiszen a fiskális és monetáris politikai beavatkozások hiányában nemkívána- 


\section{Tudományos mühely}

tos ingadozás következne be, azonban a nem megfelelố gazdaságpolitika gyakran okozója a gazdaság ingadozásának. Legfontosabb állami feladat a gazdasági stabilitás fenntartása, ami az egyenletes gazdasági növekedés, a teljes foglalkoztatás és az árstabilitásra való törekvés, valamint a belsố és külsố pénzügy egyensúly megôrzése. Az állami gazdaságpolitikai eszközök kombinációinak alkalmazását segíthetnék a közpénzek felhasználásának belsố kontrollrendszer elemei, amelynek létrehozása, múködtetése biztosíthatja a szervezet kitûzött céljainak elérését, valamint a rá bízott vagyon gazdaságos, hatékony és eredményes használatát.

Az Alaptörvény 38. cikk (5) bekezdése szerint az állam és a helyi önkormányzatok tulajdonában álló gazdálkodó szervezetek törvényben meghatározott módon, önállóan és felelósen gazdálkodnak a törvényesség, a célszerúség és az eredményesség követelményei szerint. Továbbá az Alaptörvény 39. cikk (2) bekezdése kimondja, hogy a közpénzeket és a nemzeti vagyont az átláthatóság és a közélet tisztaságának elve szerint kell kezelni.

A felelôs vállalatirányítási rendszer hatékony múködése az állami tulajdonú gazdasági társaságoknál, valamint a teljes nemzetgazdaságban elôsegíti a piacgazdasági elvek szerinti múködést és az ahhoz szükséges megbízhatósági kritériumok teljesülését a megfelelő speciális jogi normákon keresztül. A közpénzfelhasználás, az állam által felügyelt és tulajdonolt szervezetek múködési hatékonyságnövelése szempontjából igen fontos, hogy ne csupán kontrollrendszer-központú legyen. A vállalati szférában már jól bevált compliance-szemlélet erôsítése általában is államhatékonysági célokat szolgál, mivel a mögöttes gondolat, hogy a magasabb szintú döntésekhez igazodjanak olyan szinteken is, amelyek felett a kontroll csak közvetett, így kiemelten fontos a többségi állami tulajdonú gazdasági társaságok tevékeny hozzáállása a jogszabályoknak való megfelelés területén.

Mind az állami, mind a vállalati belsố kontrolling célja a (köz)vagyonnal és (köz)pénzekkel való szabályszerú, gazdaságos, hatékony, eredményes gazdálkodás biztosítása, valamint a korrupciómegelôzési intézkedés hatékonyságának a fokozása.

\section{FelHasZnált IRODALOM}

Aradi Zsolt (2012): A költségvetési gazdálkodás. NKEWekerle program, Budapest.

Bán Erika (2018): Az ellenốrzés produktivitást segítố szerepe és fejlesztése a magyar kkv-szertorban. PhD-értekezés, Szent István Egyetem, Gödöllô.

Benczes István - Kutasi Gábor (2010): Költségvetési pénzügyek. Akadémiai Kiadó, Budapest.

Bárczi Judit - Szabó Zoltán - Zéman Zoltán (2014): A kockázatkezelés controlling vetületei. Controller Info, 2. évf., 1. sz.

Chikán Attila (2008): Vállalatgazdaságtan. Aula Kiadó, Budapest.

Hágen István Zsombor (2008): A kis-és középvállalkozások versenyképességének növelése kontrollinggal. PhD-értekezés, Szent István Egyetem, Gödöllô.

Kárpáti József (2013a): Közigazgatási kontrolling. Doktori értekezés, Szegedi Tudományegyetem, Szeged.

Kárpáti József (2013b): Vállalati kontrolling módszerek alkalmazási modellje az állam múködésének értékelésében. In: Bajmóczy Zoltán Elekes Zoltán (szerk.): Innováció: a vállalati stratégiától a társadalmi stratégiáig. JATEPress, Szeged, 253-269.

Lentner Csaba (2013): Közpénzügyek és államháztartástan. Nemzeti Közszolgálati és Tankönyvkiadó, Budapest. 


\section{Tudományos múhely}

Misz József (2007): A makroökonómia alapjai. L’Harmattan Kiadó, Budapest.

Pavlik Lívia (2017): Verseny és controlling a közszféra egy fontos szegmensében, a felsôoktatásban. Pénzügyi Szemle, 62. évf., 1. sz., 48-70.

Szóka Károly (2007): A pénzügyi-számviteli tervezés és a controlling összefüggései és gyakorlata. Doktori értekezés, Nyugat-magyarországi Egyetem, Sopron.

Tóth Antal - Zéman Zoltán (2017): Stratégiai pénzügyi controlling és menedzsment. Akadémiai Kiadó, Budapest.

\section{JogSZABÁLYOK}

Az államháztartással és közpénzügyekkel kapcsolatos, aktuális törvények, rendeletek:

2011. évi CXCIV. törvény Magyarország gazdasági stabilitásáról

A költségvetési szervek belsố kontrollrendszerérôl és belsô ellenôrzésérôl szóló 370/2013 (XII.31.) kormányrendelet

A nemzeti vagyonról szóló 2011. évi CXCVI. törvény Magyarország helyi önkormányzatairól szóló 2011. évi CLXXXIX. törvény 